\title{
ENGLAND'S WAR AGAINST THE SOUTH AFRICAN REPUBLICS PART I
}

\author{
by Colonel Romeiko-Gurko.
}

\author{
Translated from Russian and Introduction
}

\author{
by Mrs. E. Foxcroft*
}

\begin{abstract}
Introduction:
Soon after the outbreak of the South African War (1899-1902) the Imperial Russian government sent military attachés to both fighting sides in South Africa. The military attaché with the British forces was Lt. Colonel Stakhovich. He was an officer in one of the best Imperial Guard regiments and was probably chosen for that mission on account of his good command of the English language.
\end{abstract}

Stakhovitch's counterpart with the Boer forces was Lt Colonel V. I. Romeiko-Gurko, also an officer of the Imperial Guard (both attachés were graduates of the Russian Military Academy of the General Staff). Prior to being sent to South Africa Romeiko-Gurko was on the staff of the Commander in Chief of the Warsaw Military District.

The choice of Romeiko-Gurko as the military attaché with the Boer forces was a very significant one. It was a tangible proof of the esteem and sympathy of the Russian Imperial government in general and of the Emperor Nicholas II in particular, towards the 'Allies' - for that is how the Boers were referred to in Russia in official circles as well as among the ordinary people. Vassili lossifovich Romeiko-Gurko was not just an officer. He was the son of Field Marshal lossif Vladimirovich Romeiko-Gurko - a national hero, and general who had distinguished himself most during the Russo-Turkish War (1977-78) and won the two great victories at Plevna and Shipka over the far superior in numbers Turks. By sending the son of such a renowned father the Emperor wanted to underline the Russian preference for the Boers - always referred to also as 'Allies' in all Military despatches.

Both military attachés regularly sent despatches to the Chief of the Russian General Staff, reporting their impressions of the course of events and military operations on the theatre of war. The interest aroused by them, especially in those dealing with the Boer forces, was so great that the Chief of the General Staff commissioned Romeiko-Gurko, upon his return from South
Africa, to write a full 'confidential' report - solely for the use of the Russian Military Academy of the General staff.

I was extremely fortunate to be lent a copy of this report during one of my visits to Moscow of which a photo copy was made at Unisa for my research on my project 'Russia and the South African War'.

The title of the confidential report - which is a book 335 pages long is entitled: ENGLAND'S WAR AGAINST THE SOUTH AFRICAN REPUBLICS by colonel Romeiko-Gurko of the Academy of the General Staff, sent as military attaché with the forces of the Allies - the South African Republics, by order of His Imperial Majesty.

\section{Table of contents of the Confidential report Preface, pages 1-8. Chapters.}

1. Brief topographical survey of the theatre of war operations in South Africa. Pages (9-20.)

2. Military organisation of the South African Republics. (21-69.)

3. Armaments and their supply. (70-84.)

4. The Commissariat. (85-96.)

5. Institutions, which influenced the course of military operations by helping the South African Republics in their struggle against England. (97-128.)

6. Military Activities of the forces of the Allies.

7. A brief outline of military engagements during the first year of the campaign. (182-252.)

8. Deductions formed so far, on the basis of the war between England and the South African Republics. (253-261.)

Conclusions. (262-280.)

Annexes. (289-335.)

The confidential report was printed at the end of 1901 by the Military typography and published by the Military-Scientific Committee of the Chief General Staff. The report included a large map 
(scale 1.6300000) of the theatre of war operations in Russian with many local names given Russian equivalents for the first time. It was drawn under the direction of a well-known military cartographer General Lt Baron N. Kaulbars - of the Academy of the General Staff — who happened to be my maternal grandfather!

Colonel Romeiko-Gurko was promoted general by the beginning of the First World War. He was in command of one of the Russian armies during the Provisional government under Kerensky, but was dismissed by the former on account of his royalist views.

General Romeiko-Gurko emigrated to France after the Russian revolution and lived in Paris as a Russian refugee. It was there that he wrote, in the early thirties, a book entitled: 'The Tsar and the Tsarina' about the Emperor Nicholas II and the Empress - his wife.

General Romeiko-Gurko died in France in 1937 ...

Having lived for several months among the fighting Boers during the South African War, Roemeiko-Gurko met and came to know several of the most outstanding Boer generals and leaders. This gave him the opportunity to give the characterisation of some of them in the last part of chapter 7 , in order to give a clear impression of them to the readers of the confidential report. Every possible help was given to him by the Boer military authorities in his research, mainly from Boer sources, for this report in which he shows himself a keen, objective observer, when evaluating the weak and strong points in the strategy of both fighting sides. There can be no doubt that Romeiko-Gurko's confidential report and his military despatches (translated by me from Russian as well as those of the others: Lt Colonel Stakhovich, with the British Colonel Ermolov's in London and Colonel Miller in Brussels, which appeared in two separate editions of 'Historia' taken from a hitherto unknown, here, source of information, form an important contribution to S.A. historians and those interested in their country's struggle for independence.

\section{A Brief outline of military engagements during the first year of the war}

The military actions of the first year of war between England and the South African Republics fall into three periods, almost equal to one other in length, divided from one other by intervals of inactivity and halts in the English advance movements. The first period, lasting from the beginning of military operations to the surrender of General Cronje and the lifting of the Ladysmith blockade, i.e. till the end of February, is characterised by the Boer passivity and the Englishmen's desire to force the opponent to give up his positions by frontal attacks. The second period, lasting until the surrender of Pretoria by the Boers, i.e. until the beginning of June, was spent in the Boer's tenacious avoidance of meeting the main forces of the enemy, and their incessant withdrawal into the interior of the country and attempts of military activity against the flanks of the general front of the advance of English troops. The latter, during this time tried to make the most out of the superiority of their artillery and at the same time undertook tactical surrounding movements, threatening an encirclement of the enemy's flanks. The third period ended in the Transvalers having to give up the railway line Pretoria-Komatipoort that is to say at the beginning of September, and was characterized by the growing activity of the allies which took the form of guerilla warfare. During this time the Boers persisted in avoiding decisive battles against the advancing main forces of the enemy. As for the English during the same period, they continued their former tactics - the advance of large numbers with strong artillery support - on the one hand - and on the other they tried by repressive measures to put a limit to the further development of their opponent's guerilla warfare. In order to achieve this objective they sent small detachments out in different directions. This gave the Boers the opportunity of encountering the enemy and of gaining victories, which although not decisive on a large scale, at least kept up their morale. After the departure from the Transvaal, of President Kruger guerilla activity increased very considerably. From that time onwards, that is, from the beginning of September, the War entered into the fourth phase, during which the parts changed: the Englishmen passed from attack to defence. The repressive measures, which they undertook became even more stern, not to say cruel. To this their opponents retaliated by an increase of guerilla warfare, first of all within the confines of the two republics, and from the beginning of 1901, also on the territory of English possessions in Natal and in the Cape Colony.

On October the 11th of 1899 the time limit of the ultimatum, sent by the Transvaal to the English government, came to an end, and it was considered that war had been declared, but it was only on the morning of the 13 th, that the Boers, 
having received news that the English troops were not budging from their positions, at first in small separate detachments, and later in stronger formations, crossed the boundaries of English possessions, and unimpeded, stepped on the enemy territory. Already for the two preceding weeks Boer commandos began to concentrate their forces close to the frontiers of the country, gathering themselves into large camps, situated mainly in the proximity of railway lines, leading chiefly in the direction of English ports, of the Eastern and Southern shores of the African continent, and also along the Western boundary of the republics. The untimely concentration of forces close to the frontiers was caused by the fear of a sudden English invasion, which would have, in the opinion of the Transvaal government, not only made it impossible for the Boers to call up their regional commandos but would have even threatened the seat of the government Pretoria. The government of the republics was massing troops near the frontiers and was not planning military actions, as having heard so much about Englands military preparations, it was quite certain of an invasion. This apprehension concerned most of all the operational direction Durban-Pretoria. Information received from camps situated on the Natal boundary confirmed this supposition. Although English troops were collecting not on the frontier itself but on Dundee-Glencoe and in Ladysmith, the population of Natal, of both Dutch and English extraction, was quite certain that as soon as war was declared the troops would be moved by rail to the frontier and would prevent the entry of Boer commandos into English territory.

However, with the approach of the time limit set by the ultimatum, opinion changed, because English troops concentrated in their camps, did not move. Having ascertained this fact from the local Dutch inhabitants, the Boers decided to cross the Natal border themselves and did so at three points: in the North near Volksrust, in the East near Vryheid, and in the West at Van Reenen's Pass. From these points the commandos moved in a concentric movement towards Dundee and Glencoe, where the English garrisons were stationed; such were the rumours. The local English population, panick-stricken at such an unexpected turn of events, fled leaving all its possessions to the mercy of the advancing enemy. In all the houses, not only in the country but in town as well, half-cooked meals and half-written letters were found. From some of these letters one can conclude that the passivity of English troops and, as a result of that, the Boer invasion, were a complete surprise to the inhabitants. The English left the railway line from Volksrust in the South almost as far as Glencoe in such haste, that the advancing Boer commandos found it absolutely unharmed. All the damage was limited to the removal of two siding rails and of a few telegraphic implements. But the assurance that the English would start an offensive, was so strong among the Boers, that expecting to move back to protect the frontiers, the commandos blew up bridges, as they moved along the railway line, fearing the appearance of English armoured and troop carrying trains. In Pretoria the dominant preconceived notion was that the English would take the initiative into their hands and therefore it was not considered necessary to work out any plan of advance into English possessions. On account of this attitude the Boer offensive turned out to be a kind of elemental, instinctive advance, started on the initiative of small groups of burghers. Nevertheless when it became quite clear that the English did not intend to take the initiative into their hands, it became imperative to plan what to do next. It was therefore decided to make an attempt to move the encampments, not only beyond the Drakensberg mountains but also beyond the Biggarsberg, in order to find among their Southern ramifications positions suitable to repel all future English attempts of attack. This had the additional advantage that the war, bringing in its wake damage and destruction of private property, would be waged in enemy territory. Besides this, at that time of the year it was easier to get fodder for horses and cattle down South.

It had never been expected in Pretoria that the English would not dare to advance, or at any rate would not meet the opponent at the border. However it seems that the conduct of the English had not been motivated by a well-thought out, mature plan, but was simply a proof of England's unpreparedness for war. Everything leads one to assume that England, preparing as she was for several years for an armed conflict with the two republics, intended to take the initiative on the spot. One can deduce this from certain documents seized at the Dundee camp and abandoned by the English, in the form of military-statistical description of the probable theatre of military operations as well as from the fact, that in spite of these preparations, the military authorities of Natal had not prepared any typographical maps south of the Biggarsberg. It is obvious that these suppositions must have been well-known among the English troops. Therefore the radical reversal of roles must have affected 
their state of mind adversely, at the same time as it raised the spirit of their opponents. The first encounters, in spite of this, were of an accidental and indecisive nature. This can be explained by the fact that the opinion, expecting the English offensive still prevailed; a defensive form of action was more in keeping with the character of the Boers and finally the state of mind of the English troops was such that they appeared to be as if feeling their way with their enemy, not daring to embark on a decisive course of action. A good illustration of this point is the Dundee action, where the English occupied a fortified camp in the dip just outside the town. A few detachments of the Transvalers began to fire into the camp from the surrounding hills. This fire did not do much damage on either side and ceased at dusk. The Boers, considering their position unsafe so close to enemy encampments, moved further away in order to return to do some more firing the next day and retire again at night. But when on the next day the Boer scouts climbed again on the hills, they had left the evening before, they were quite at a loss what to make of it when they saw the English camp without sign of life. It turned out that the English had also withdrawn but not in order to return at dawn, but in order to try to link up by cover of night, with the main English forces of Natal, stationed at the time near Ladysmith.

The Dundee garrison left behind not only all its untouched supplies of food and ammunition but all its wounded as well, including its commander General Symons. The result of the firing, which had taken place on the previous day had appeared so unexpected and successful to the Boers, especially because of the extensive stores, which had fallen into their possession, that they did not think of pursuing the enemy; they did not even send scouting parties to ascertain the direction in which the enemy had retreated. This gave the English detachments the opportunity to join General White's forces near Ladysmith with complete impunity. A few days later the Boer detachments were joined by other troops from the Transvaal, which were moving along the railway line and from the Eastern border of Natal, as well as by men from the Free State, who came from the West. It is impossible to ascertain the exact numerical strength of the Boers who had gathered around Ladysmith. To begin with there cannot have been more than 8000 . It seems that General White, had no intention of locking himself up in Ladysmith, as in a fortress, but only wanted to use it as a base. The town had many stores and he meant to act from there along the inner operational lines and to make a stand from there against the Boer Commandos, who were moving concentrically towards Ladysmith. At any rate the detachment, which was attacked at dawn of October 30th on Nicholson's Nek, later called Small Amajuba, had been sent out in order to protect the flank of the general advance towards the North, against one of the approaching Boer detachments.

The English detachment surrendered to the Johannesburg Police after a faint-hearted resistance. 1300 men and 41 officers were taken prisoner. The chief reason for this important blow to English fortunes lay in a complete lack of any protective measures. The English detachment, which had stopped on the edge of a large plateau during the night march, did not take the trouble to send out scouts to the other side of the plateau with the coming of day. On account of this the approach of a relatively insignificant Boer commando, numbering 450 men, and their sudden firing, took the English utterly by surprise. Not seeing the approaching detachment, the English could not judge its strength and put out a white flag unsuspecting that they were surrendering to an enemy four times weaker than themselves.

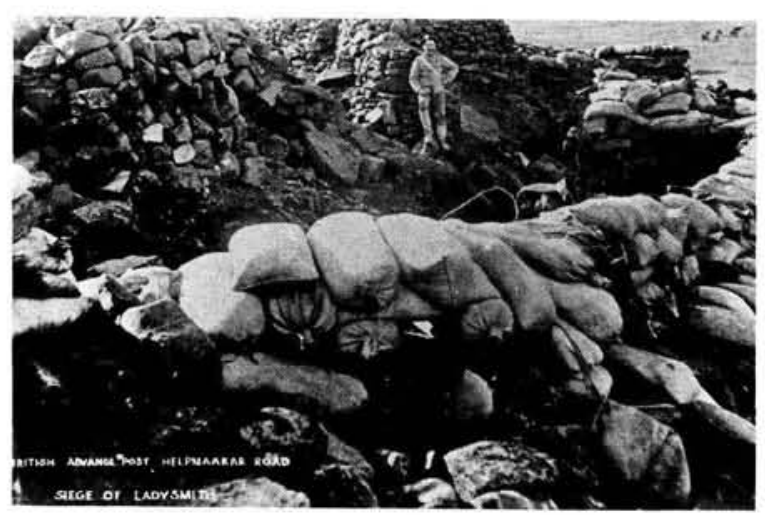

Siege of Ladysmith, A British outpost on the Helpmekaar Road, 1899-1902.

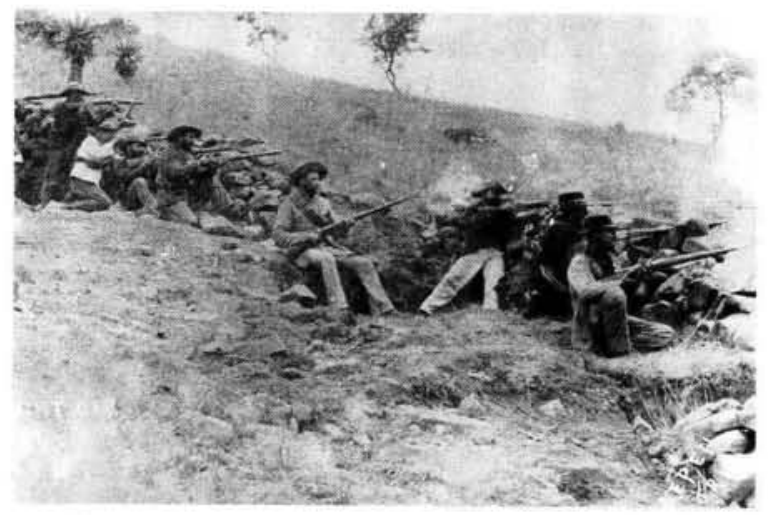

Siege of Ladysmith. Boer sentries with rifles. 
After several failures, of which the action at Nicholson's Nek, was the most important, the English forces, which were the bulwark of all Natal, abandoned any active warfare and enclosed themselves in Ladysmith, awaiting the arrival of further reinforcements from home. The large food and ammunition supplies concentrated in Ladysmith made it possible for it to withstand a prolonged blockade. But the topographical emplacement of this town and the surrounding countryside, situated in the centre of a mountain ring, offered no advantages at all to the defending side. It was only the limited number of large calibre guns, at the Boers' disposal, which saved the Ladysmith garrison from the after effects of shelling. Although the three Boer siege guns did not cause many losses to the English, they did force them to take shelter in the fort, in basements or under other cover, for days on end. At any rate both the town and the English military camp seemed quite deserted. It is said that when it got dark, and the Boers ceased firing, the town, the camp, and the guard positions came to life. But it is beyond doubt that the prolonged inactivity and the hiding could not but adversely affect the besieged garrison. The only place where one could see great activity was in the hospital camp, which upon a request from General White, acceded to by General Joubert, had been moved far beyond the defence line and placed right against the positions of the attackers at the base of the Isim-Bulwana mountain on the banks of the Zandriver. One could clearly hear the conversations taking place in the English hospital camp, from the advanced positions of the Boer sentries. The hospital camp was so large that its tents could easily house at least half of the Ladysmith garrison.

From the moment that the English forces had taken cover in Ladysmith, the allies commanded free entry into the capital of NatalPietermaritzburg and further as far as Durban, where Boer commandos were expected from one hour to the next. In order to reassure the population of the town of Durban, the authorities had brought out and mounted upon the heights surrounding Durban, all the old guns, some of which could only be loaded by spherical cannon ball through the front of the muzzle. But their fears were unfounded. After the main forces of the allies had entered Natal and had struck camp, occupying positions in the mountains surrounding Ladysmith, only small detachment moved further down towards the south - the total number of which was not more than 3000 and even these did not go beyond Estcourt, where they did not stay. Meanwhile, since the Boer commandos could not bring themselves to undertake any action in the direction of Pietermaritzburg, although everything was most favourable for such a move, it would have been to their advantage to occupy the strong defensive positions around Estcourt and to await the approach of the English reinforcements there, for sooner or later these had to go to the help of the 10000 men strong army of General White. Had they acted in this way the Boers would have had some freedom of movement between the forces besieging Ladysmith and the forces barring the way, along which one could expect the arrival of those going to the rescue of the besieged enemy garrison.

A break through of the forward positions gave one the opportunity to move back and to occupy others in the rear, and had the English sent a column in an encircling movement, the Boers taking full advantage of their mobility, could have confronted it and barred its further advance. At the same time they could have constantly harassed the communication lines of the forces moving to the rescue of Ladysmith. But all this required enterprise and at least planning, of which at that stage of the campaign the Boer commandos were yet not capable. Therefore the allies chose to occupy such positions, which should perforce be crossed by forces moving to the rescue of Ladysmith. The best of these positions were those on the left bank of the Tugela river, but they were so close to the blockading lines, that the camps of the detachments facing South, were almost touching those surrounding Ladysmith. Having completed the blockade arrangements around Ladysmith, General Joubert did not immediately decide to await passivley the surrender of the garrison, which would be forced to do so after it had exhausted all its supplies. Urged especially by orders from Pretoria, twice he gathered together the Krygsraad - during the second half of November and at the beginning of December, proposing to the commandants to take Ladysmith by storm. On both occasions the gathering did not only agree with him but even worked out plans of attack. However the first one did not take place because the commandants, appointed to lead the advancing columns, came together on the eve of the proposed attack and passed the resolution that the enterprise was too risky. During the second storming, which actually took place on December 6th, the first Boer onslaught of the hill dominating the city and which was the key to the English position, was successful to begin with, but was later repulsed by the English, because the other 
two columns, which were supposed to attack the town from other directions, set off too late. This failure removed any desire in Joubert and the troops subordinate to him, to attack Ladysmith once more. Meanwhile in all probability, another attack undertaken at the end of January, when the garrison was physically exhausted owing to lack of food and mentally depressed owing to its inactivity, would have been successful. The best proof of this lies in the fact that when General Buller's troops strained all their might, in order to dislodge the opponent from the left bank of the Tugela, and twice partially succeeded in doing so - the defenders of Ladysmith itself, did absolutely nothing to help Buller, by, for instance, making a sortie, which had every chance of success, as the numerical strength of the forces blockading Ladysmith on a periphery of 45 miles, had shrunk to $2000-3000$ men.

The reinforcements, which had arrived during this time in Durban, were hurrying to the rescue of General White and his men. The absence of resistance between Durban and the valley of the Tugela, made the English troops and their new commander in chief General Buller, feel certain that the last step for the liberation of Ladysmith, and the last march to the point in question would be easy. Because of this apparent certainty in an easy victory awaiting them, the shock of the first failure lying in store for the English at Colenso on December 15 th was all the greater. The actual

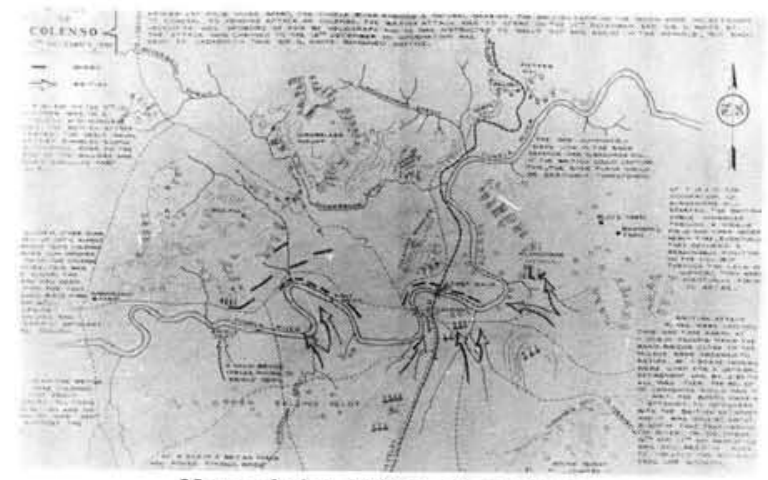

Map of the Battle of Colenso.

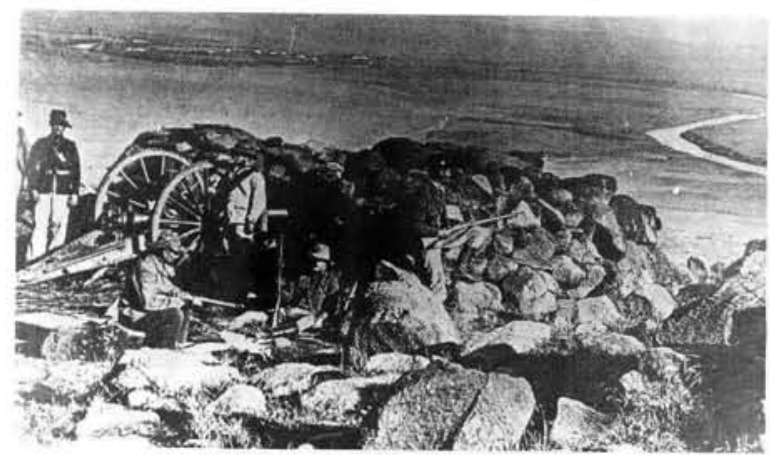

Overlooking Colenso Battle-field. mishap was not so important in itself or in its results; if it had not been for the loss of eleven guns, the moral effect from it upon both fighting sides, would not have been very significant. The whole action boiled down to a frontal attack of a few battalions and two batteries, which unexpectedly had found themselves under cross fire and which because of it bore rather heavy losses in a relatively short period of time. If it is understood that the losses stopped the advance of the battalions, and deprived them of the possibility of continuing the attack, then one cannot understand why this was considered a sufficient reason, not only to withdraw those particular formations from the enemy fire, but to give the order of general retreat of two forced marches.

This was all the more incomprehensible since the opponent having stopped the attack, considered that a sufficient success and did not make the slightest attempt at pursuing the retreating Englishmen. Meanwhile Buller acted in the same manner, after the second and the third attempt to dislodge the Boers from their positions on the left bank of the Tugela. Buller tried again to break through and at the same time endeavoured to encircle the right flank of the allies positions. But this movement was executed so slowly that the Boers had time to prolong their positions towards the west so that the blow struck not where it was intended but against the centre of the right sector of the defended positions. The Boers, after an English attempt lasting for two days, to dislodge them from the extreme right flank, succeeded in almost entirely clearing from enemy troops from the tactical key of the entire right sector - the position of Spioenkop hill. Attacking unexpectedly, during the night, the English won this dominating position, but they did not take advantage of their success, although under cover of darkness they brought in many more troops to the top than the size of area warranted. The English emplacements were arranged in six rows and the men lay almost next to one another. But as no serious attempt was made to move elsewhere this concentration of men so close to each other only increased the number of victims from rifle and artillery fire. Meanwhile two Boer groups, having come to the conclusion that the loss of Spioenkop had decided the fate of the defence of all the positions, retreated to the North. But the English did not make the best of this weakening of the already scanty forces of the allies. Having remained for two days and nights at the top of Spioenkop, the English left it on the third day, in the same way as they had occupied it 
under cover of darkness and in the same way as after the battle of Colenso, all Buller's forces, retreated as far as the station Frere, unimpeded by their opponents. This second success made

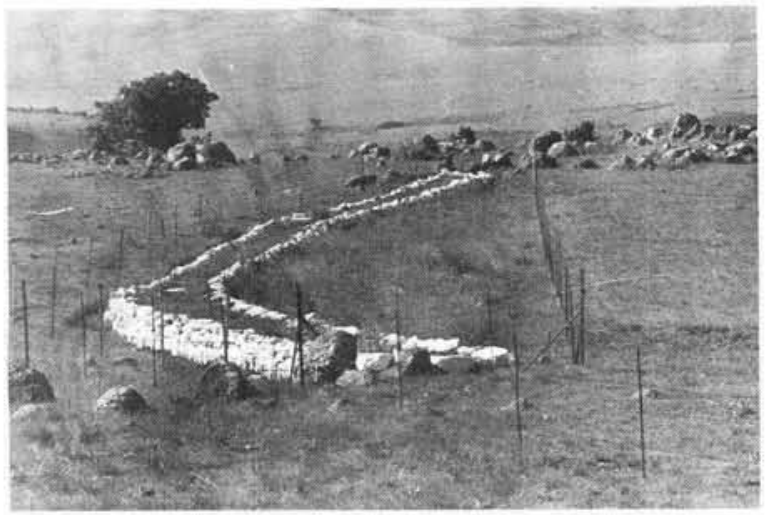

Battle of Spioenkop. One of the main trenches. Photograph taken 1975.

the Boers feel that is was quite useless to undertake any active steps. They became convinced that the English would continue with their frontal attacks, which would procure them new successes and would give them the opportunity to shoot down the enemy, without leaving their safe positions. Each action in pursuit of a retreating enemy appeared to them as presenting a certain risk. The simple Boers declared with complete sincerity: 'The Lord gave us life for a better purpose than to be killed in the open field like wild goats'. Repulsing the attacks of the enemy the Boers wanted to be quite sure of what they were doing.

The insignificant losses, which they had borne both at Colenso and at Spioenkop compared to the English confirmed them in their belief. And truly the behaviour of General Buller could only strengthen this opinion. Two weeks had not yet elapsed when he undertook a third attack - this time into the centre of his opponent's general disposition. Having prepared the way for the attack by artillery fire, he occupied a central sector of the Boer position and appeared to be firmly entrenched on the left bank of the river. However, after two days, having not been strong enough to secure the adjoining sectors, Buller, once again, in the dead of night, moved his forces back to the right bank of the river, and then, not in any way forced to do so, once more moved back together with supplies and heavy naval guns as far as Frere station. Only the day before the retreat endless columns of supplies were moving along the road from the station Frere towards the Buller troops, which were camping in the triangle formed by the confluence of the big and the little Tugela rivers.
The following day all this was moving back in the opposite direction.

The partial success, which the Boers met with on February 5th, when they were obliged to abandon their impregnable position as it seemed to them, on the left bank of the Tugela and lost fifty men in three days from their ranks, made the Boer commanders doubt the impregnability of this position in the event of another English attack. A large Krygsraad was called to discuss this question on February 11th presided over by general Joubert and composed of all the commanders and field-cornets gathered from around Ladysmith and the Tugela. Although one of the participants expressed himself in favour of a more dynamic course of action, all the leaders and with them the vast majority of the assembly, declared themselves in favour of the proved method, which it had seemed to them had achieved such good results so far - that is to say the passive defence of the positions on the left bank of the Tugela. With this in view it was decided to strengthen the fortifications which had been constructed along the whole position still further on the grounds - as it was expressed by General Botha that: 'They cannot allow the loss of fifty men from their ranks each week'.

But before describing the last act of the Ladysmith blockade and of the defence of its approaches, it is essential to become acquainted with what was happening on the other theatres of war operations.

The burgher commandos of both the republics, grouped on the Western and Southern border, having received information about the absolute insignificance of English armed forces, situated in the frontier zone, decided to profit by this fact and to move forward before the arrival of fresh English troops - in a word, to advance in the Southern theatre i.e. on the border of the Orange Free State and of the Cape Colony, the main object of this advancing movement was to fortify positions on the mountain ridges which stretch parallel to the Orange River at a distance of about 70-100 miles to the South from it and to await the arrival of the enemy there. Separate commandos from border regions had crossed the Western frontier in order to disrupt the railway communications between Kimberley and Mafeking. Afterwards they joined those commandos which had been called together against these towns. These commandos in their turn, seeing that the garrisons of these towns were quite passive, decided to get closer to them and to take them by force. The resistance, 
which the English offered, caused the Boers to begin their blockade. In principle both the Transvaal government and the Commandant General Joubert were against the regular blockade of these towns, partly because the lack of artillery made it impossible for the Boers to make any large scale bombardment. But the heads of units were of the opinion that since they had no other possible military objective in view, it was best for them to busy themselves if not with a siege at least with a blockade of these well-populated spots. Having come to this conclusion, they were aware of the fact that the English would, at any rate try to make attempts to free the besieged, especially on account of the presence in Kimberley of the man of destiny of South Africa, Cecil Rhodes. In order to hold up English troops, which might be advancing from the South, Boer forces were disposed better than on the Tugela, moving much further down, as far as the crossing of the railway line De AarKimberley and the Orange River. This gave them the opportunity, while holding the frontal attacks of the enemy, to shift from one position to the next and consequently to protect them.

A series of frontal attacks, carried by the English at Belmont, Graspan and at the Modder River, terminated in another frontal defeat at Magersfontein. This action had much in common with the battle at Colenso. Here the Boers were also occupying positions shaped as a bow into which the attacking English Battalions advanced and where they suddenly found themselves under cross fire. Two batteries, in the same way as at Colenso having moved too far forward and having found themselves in the firing zone, bore, in a short space of time large losses in both horses and men, after which fire ceased and until evening 12 silent cannon muzzles were pointing against the positions of the Boers. The English affirm that some of the men in charge of artillery guns, who had remained alive, lay down next to them pretending to be dead. But the Boers, although they knew that after the infantry's retreat these guns had been left unprotected, did not venture into an offensive in order to capture these, abandoned guns. In all probability the attempt to get possession of them would not have passed without some victims, as the field was still under fire from other English batteries. The necessity to expose themselves to danger, as well as the lack of knowledge as to how best of all to achieve their objective, was, as admitted by the Boers themselves, responsible for the lack of volunteers. When night came the English removed their guns.

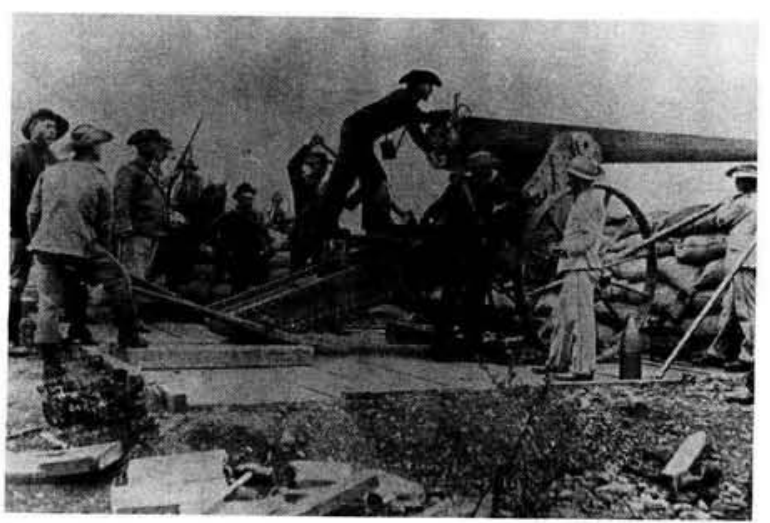

Boers firing a Creusot cannon from the entrenchment during the siege of Kimberley.

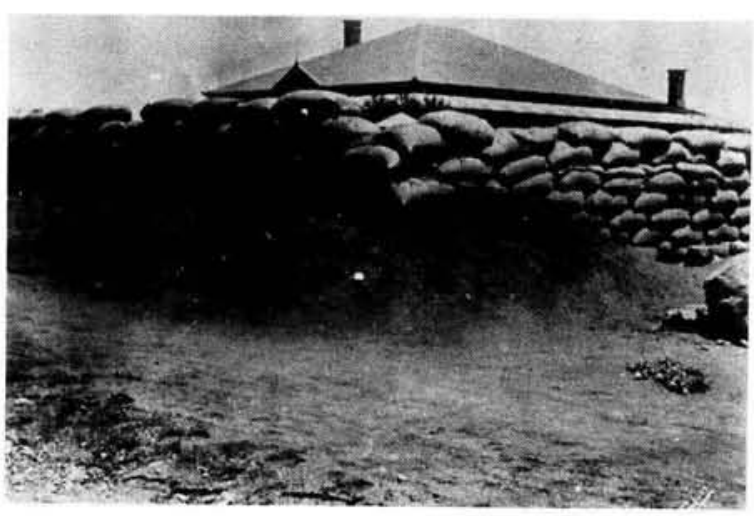

Siege of Kimberley: a barricaded villa.

This last attempt to lift the blockade of Kimberley exhausted the energy reserve necessary for an offensive, among the troops of General Lord Methuen. Instead of the attacker he became the defender, although the Boers did not undertake any serious attacks against him and did not even harass his communication lines much. The successfully repulsed attacks at Magersfontein and the subsequent inactivity of Lord Methuen, convinced the Boers that their positions were impregnable and made them deduce that if the English would attempt another liberation of Kimberley, they would once more use a frontal attack. Besides this General Cronje had the preconceived notion, that the English would never risk moving far from the railway line. It must be said that not everyone in Pretoria shared this view and some forsaw the possibility of a break through of the defence line on the Modder River as these positions were not considered as strong as those on the Tugela. The President even wired to Cronje asking him whether he did not think it possible to take Kimberley by storm, in order to finish with it once and for all. General Cronje replied that he was against such a plan, but that if the President gave him orders to attack, in such a case he would try to persuade his men to storm 
the city. The President did not dare to give a formal order and the storming of Kimberley did not take place. Taking into consideration the unpopularity of such a move among the forces blocking Kimberley, apart from a few dozen foreigners, who hoped to enrich themselves in the diamond mines, one can assert with a certain amount of certainty that such a storming had few chances of success.

One can assess the extent to which the Boers and their chief considered their positions impregnable from the fact that, in spite of being informed about the approach of considerable English forces, half of the men still let their horses graze some 25 miles away in the care of natives, and they themselves remained in the trenches.

One must take into consideration the fact that each Boer, deprived of his mount, looks on himself as thrown out of the ranks. In such an eventuality nothing will keep him in the position he occupies, if there is any possibility of his having to retreat from it. This is due to the fact that the Boers are not used to walking at all. When some of the men lost their horses during the second and especially during the third phase of the campaign, and at the same time could no longer return to their farms, which were in territory occupied by the enemy, they moved about in wagons, 10-15 men in one waggon.

As the Boers did not attach much importance to reconnoitring the movements of General French's column, sent out to lift the Kimberley blockade by attacking the Cronje position in the rear, was only discovered when it had crossed the Modder River in full formation, i.e. two days after the beginning of the encircling movement of the English cavalry. When he first heard of this General Cronje would simply not believe the news and said to the young Boer who had brought the news that "Fear has big eyes and that no English cavalry could be there". General de Wet who was placed to the East of the path chosen by the column of General French, although he received the news of the advance even later, treated it quite differently. $\mathrm{He}$ and his men advanced immediately to the spot where the English had crossed the Riet River, but he only succeeded in capturing supply transport meant for Kimberley. So though General de Wet was satisfied with its capture he decided that the entry of the English cavalry would only worsen the position of Kimberley's garrison, whose supplies, according to Boer sources of information, were almost at an end. Therefore General de Wet's first move was to hide the supplies in a safe place. But General French's advance achieved an important though quite accidental success. Moving forward the column walked between General Cronje's detachment and the droves of horses entrusted to the natives. The latter instead of trying to bring the horses back to the camp by night, rushed in the Northly direction, thus leaving their masters without their mounts.

When General Cronje at last understood the whole situation i.e. that Lord Robert's entire army, had actually crossed the Riet River below Jacobsdal, and was apparently intending to move on to Bloemfontein or to follow in the tracks of French's cavalry into Kimberley, inspite of the firmly grounded opinion that the English would never dare to move off the railway line, he was faced with two choices: either to retreat Eastward, defending Bloemfontein or to advance into the rear of the English army, thus cutting it from the railroad, which served as its line of communication. But the fact that he had a whole train of waggons which he did not wish to abandon or destroy, and also the additional fact that half his men were without their mounts, forced him to give up the second alternative. As long as Cronje's men considered their position quite a safe one, in the sense of possible retreat, the absence of horses did not reflect on their military capacity. But from the moment when the state of affairs became doubtful, men on foot thought of one thing only - how to get away from the proximity of the enemy. In such circumstances it became impossible to plan any action. Meanwhile an attack into the rear of Lord Robert's army, carried out even with a minimum of energy, could well have brought about a catastrophe for the English army. Deprived of its food supplies by General de Wet, and being very numerous, it could not have found the means of supplying provisions in a sparsely populated land. It could not have managed without its supplies from the railways, which were left almost undefended. But General Cronje thought that he had made the wisest choice - to retreat with all his men and supplies to the East, not doubting for a moment that he would be able to lead his detachment on to the road leading to Bloemfontein and there to cut the path of the enemy's advance.

A shortage of oxen, as some of them had been chased away Northwards with the horses and the Boer's inability to make long marches on foot, forced General Cronje to move with extreme slowness, doing hardly 10-15 miles per day. As a result of this when his men reached the crossing 
of the Modder River at Paardeberg (the road leading to Bloemfontein crosses to the left bank of the river at this spot) where he had intended to spend the night in order to continue at dawn the next day in the direction of Bloemfontein he was overtaken first by the column of general French, which had come back from Kimberley and was waiting to intercept him and secondly by Robert's infantry. Thus having begun his move on February 14th Cronje's detachment had only covered some fifty miles in four days. If all his men had been mounted they would have reached Bloemfontein with ease. On the 18th of February the Boers fought back the English attack with big losses. After that thinking that the English would be satisfied with artillery fire, they thought only of one thing - how to entrench themselves as deeply as possible into the ground in order to find safety from the lyddite bombs. In this they succeeded to a considerable extent as during the nine days of the bombardment the ranks were reduced by 200 men only through loss of life or wounds.

But if the men on foot were forced to remain in the valley of the Modder River, for they did not consider it safe to move in the open veld under enemy cross fire - the men who had their horses with them reasoned otherwise. Without waiting for a command, these men of whom there were about 3000 at the beginning of the retreat of General Cronje, and without asking anyone's permission, they began in their usual formation, in small groups, leaving the camp and joined the forces of General de Wet unhindered or returned to their farms; for they lost all their possessions which had been left behind with the supplies.

During this time the Krygsraad gathered every night at the Paardeberg camp and plans of action were discussed as well as the existing chances of escape. The men on foot who had been forced to remain at Paardeberg now realized clearly; that firstly they had to deal with the whole of Lord Roberts's army, whereas they were fewer than four thousand men, and secondly that any further movement on their part would perforce involve them in constant fights in the open veld. If one adds to this that being on foot they no longer considered themselves as first-line soldiers, one can get some idea of the state of mind of the men. It must be stated that the English did not establish a very strict blockade, for single riders were not only able to leave the camp daily but to ride out and return to it unimpeded. At the Krygsraad presided over by General Cronje suggestions were often made to make an attempt to break through, for there was little or no hope of help coming from outside.

General de Wet's forces were unsufficient and the calling up of other detachments from the Cape border or Natal would take too long. But the vast majority of votes at the Krygsraad were against attempts to break through, pointing out that it would result in too many victims, slain in vain as the attempt might not even be successful. As the supplies of essential victuals were running low the day drew near when a decision would have to be made - to either break through or surrender - the Krygsraad sessions became more and more stormy. The minority demanded to try and break through, and the opponents of this plan attacked its uselessness with an even greater show of temper. The members of the Krygsraad, who usually conducted their discussions with striking calm, absolute order and decorum now reached the point where they were threatening that they would order their men to shoot those who did not agree with the majority's decision. The session of the last Krygsraad took place on the night of the 26th to the 27th of February. No definite decision was reached. After it some of the officers who were still in possession of their horses left the camp during the night for they were convinced that one could no longer expect a serious attempt at breaking through. The next morning Cronje surrendered.

In order to understand clearly why the majority of those present at the Krygsraad were against attempts to break through, one must take into consideration the fact that the character of the Boers is such that they are incapable, when in large numbers, of acts of heedless valour or of what they call a pointless risking of their lives. Their basic principle in a fight - is the desire to inflict as many losses as possible on the enemy with the minimum of risk to themselves. The damage done to the enemy is calculated by the number of men knocked out of its ranks. And how can one expect that a simple, peaceful citizen with little education, should gauge success differently and should take into consideration the moral effect of this or that military encounter or the degree of disorganization, introduced into his own or his opponents armies by the outcome of a battle or of a military operation, such as they are understood in regular armies; these men have no conception of such things! Thus in this particular case the Boers could not foresee the moral effect which their capitulation would have on all their fellow citizens of the republic. However, they were well aware of the fact that an attempt to 
break through might cost hundreds of victims to their side and that they could not even be sure of inflicting any losses to the enemy, or of reaching the desired result that is being at large. Had this been a regular army, it would have been taken into consideration, that a capitulation, without even one desperate attempt at breaking through, would be a stain on the military honour of the detachments, which had laid down their arms. But no one raised this question, for the simple reason that there is no notion of military honour of a detachment in the Allies armies because each individual does not look upon himself as a part of a collective whole but only as a separate being his personal I. Therefore one cannot envisage this question from that angle and in discussing this matter one must not charge people of treating with contempt a sentiment that is unknown to them.

During the period when Cronje's forces were being surrounded there was a certain amount of communication between them and the troops which had gathered together between the English positions and Bloemfontein. Although they got into touch with the blockaded camp by means of a heliograph, they could tell them nothing encouraging, for they considered themselves, and were in fact too weak to try to repulse Roberts's forces, and the reinforcements from Natal and the Cape Colony were not expected until March 5th. Actually they only arrived in the afternoon of the 7 th of March, that is to say after De Wet's withdrawal from his position at Poplar-Grove. On February 27th another attempt was made to get into contact by heliograph with General Cronje, but - although no answer had been received, nevertheless none wanted to believe the news of his surrender. President Steyn, knowing what an impression the news of Cronje's capitulation would have, delayed making it public for several days and it appeared only in a government bulletin on March 2 nd. From the moment that Cronje had been surrounded, an order had been issued to all commands serving on the Southern border of the Orange Free State to move towards Bloemfontein. This was done in the hope that they would succeed in forming a concentration strong enough to strike the enemy from outside and thus to free Cronje and his men. This was an important omission. The assignment of the detachment stationed near Colesberg was - making the most of the fact that Lord Roberts was far from his lines of communication and that they were guarded by a much smaller number of men - to make daily small attacks on the railway line De Aar-Kimberley and to destroy it in two or three places Lord
Roberts's army, deprived of its supplies, and which was already getting only half its rations would have been placed in critical situation. It is possible that its supplies would have come to an end before those of Cronje. It is difficult to assess all the possible consequences of this! But at the time nobody thought of guerilla warfare, no one dared to attack lines of communication and people still imagined that the advance of the English army could be held up by a consistent defense of strong natural defenses. Such a defense was chosen on the way of Lord Roberts's advance on Bloemfontein at Poplar-Grove.

It was hurriedly fortified with trenches and occupied by 4000 men, partly the forces of General de Wet, partly with men who had come from Cronje's camp. Besides these, reinforcements were expected from the Cape Colony border and from Natal. The decision to concentrate Boer forces on the probable path of the enemy towards Bloemfontein, forced the government to move some of the forces acting on the Natal theatre and thus to further decrease their number. But apart from this the fighting quality of the troops in the South-Eastern sector had been affected first by the news of Cronje's encirclement and then the premature ante factum news of his surrender. An almost instinctive feeling of apprehension, lest the way back might be endangered spread among the burghers who having received no regular army training and not being used to military discipline were more prone to be affected by the bad news about Cronje and those who were with him. This was probably the reason why all General Louis Botha's (at the time commanding the Natal forces) efforts to induce certain commandos to remain on the heights above the right (Southern) bank of the Tugela near Colenso, were unsuccessful from the moment that it became clear that Buller would make a crossing of the Tugela river once more. Meanwhile the approaches to the fords as well as some of the Boer positions on the opposite shore were protected from the right bank heights. Having occupied the right bank height without a fight, the English using flank fire, gradually forced the Boers to clear the hills, which adjoined the left banks of the Tugela.

It was impossible to look for positions further to the North as immediately beyond the troops, defending the Tugela, were the positions blockading Ladysmith. This caused the necessity to lift the siege. The retreat was carried out by the men in a fairly orderly fashion, for although as usual everybody went how and where he wanted to, he 
did so without panic or haste. The same cannot be said about the supplies camp overcrowded with natives. There was absolute panic there. This was best demonstrated by the river fords with their narrow descents and ascents. If the English had acted a little more energetically it is quite certain that they could have seized all the baggage train with the supplies. But Buller, satisfied with the lifting of the siege, repeated the mistake, which had been committed more than once by his opponents, i.e. he made no attempts at pursuit whatsoever. This gave the Boers the opportunity to remove not only their supplies but also two guns which had remained on siege emplacements. Once the retreat had begun it became quite impossible to stop the groups until they had reached the Dundee-Glencoe line, for the men belonging to different camps had all got mixed together. In order to re-establish order it was necessary to have not so much time, as space and certitude that all danger of possible enemy pursuit had passed. The contact with the enemy was broken, but the fault in this lies more with the English than the Boers. It was their duty and to their advantage to follow the mixed up detachments step by step, and on their heels to try to cross not only the Biggarsberg but the Drakensberg as well that is the last serious obstacle on the operational route DurbanPretoria. In actual fact the broken contact was re-established in time not by the English who remained idle at Ladysmith but by the retreated allies, who having got over the first after effects of the lifting of the siege of Ladysmith and the disorderly retreat to the North, began to again in small parties cross the Biggarsberg and even to harrass the English forward defenses.

The English were undergoing a similar phase of inactivity in the South-Western theatre after the capture of General Cronje. This was explained by their waiting for further supplies from the railway line. During this time the Boers, instead of impeding the arrival of supplies, removed their troops from the Cape Colony and Natal and concentrated them on the probable path of the Roberts' offensive, hoping to bar his way to Bloemfontein. But at the moment when Lord Roberts renewed his advance, these detachments had not yet had sufficient time to form and at the position at Poplar-Grove, on a front stretching for 30 miles, with important undefended gaps, the English were met by only 4000 Boers, who had seven guns. It was obviously beyond their strength to stop the English frontal attack as well as fight back enemy columns moving from the rear. The latter required a knowledge of manoeuvering which the Boers simply did not possess. Nevertheless the commander of the assembled Boer forces, General de Wet, intended to repulse the English, although he did not even have any reserves to face any possible eventuality of battle.

At the same time it seems that he did not take into consideration, the moral effect of the encirclement and capture of Cronje and his men. It was sufficient for French's column, which had entered through a wide and undefended gap of the Allies left sector to be spotted and all the detachments, not waiting for orders from their commanders, left their positions and bagan to move towards Bloemfontein, for they came to the conclusion that the English column might be cut off from them their way of retreat. One cannot deny the fact that French's cavalry might very well have done so. The picture of the retreat was the same as at Ladysmith - i.e. a slow and calm withdrawal of men who had been in the fighting lines, although they had lost all semblance of organisation, as each man moved without trying to keep up contact with other men of his camp. As for the baggage train - there was absolute chaos there, especially thanks to the natives, who were making an indescribable noise and racket chasing their oxen and mules. But as the movement of the English forces was again stopped for two days, the Allies' baggage train had time to assume some semblance of order, as soon as it had gained some distance from the enemy. One cannot understand what caused Lord Roberts to stop at Poplars-Grove, having done only one short march. If it was a lack of provisions or fatigue, it would have been better for him to remain at the former positions at Osfontein not for ten days but for at least two weeks. After that he could have forced the Boers to abandon their positions and to have chased them away without any stops.

In order to put an end to the further advance of the English, General de Wet and, General De La Rey, who arrived on the day of the Poplar-Grove retreat, could have only confronted the English with a small, assembled with difficulty, command of burghers and detachments of Johannesburg and Pretoria Police (the latter formed the personal escort of President Kruger, who came to visit De Wet's forces on March 7th, at that very moment when they were beginning to abandon their positions at Poplar-Grove). De Wet and De la Rey disposed their men, less than 1000 in all, on small hills at Abramskraal. These hills barred the main road, leading to the capital of the Orange Free 
State. It would seem that such a handful of men would be quite powerless to stop the advance of Roberts's main forces, moving in that direction. Nevertheless, owing to the steadfastness of the detachments of police, the Boers succeeded during a whole day, March 10th, in holding up the English advance till night-time. This gave an opportunity to the disordered commands and to the baggage train to move further and escape the attack of the English cavalry. During this time the Generals De Wet and De la Rey tried in vain to re-estabiish order and to assemble the men of the different camps, who had got mixed up together. These were decreasing in numbers as many of them not knowing where to go - whether to defend the capital or move North towards Kroonstad, preferred to take their ox-wagons and make straight for their farms. It is difficult to say what guided them in such behaviour - whether they wished to evade all further participation in military operations, or simply wanted to get back home, in order to assemble together again and fight later. Most probably the majority of the people moved unconsciously without definite object in view.

Seeing that it was impossible to gather his men around him, De Wet made a very bold, and at the same time the most sensible decision. He took upon himself to make the best use out of the arbitrary return home and in as far as possible to, take charge of it himself. He ordered the men who had still remained close to him to go to their farms, taking their heavily laden ox-wagons with them and upon arrival home to notify all the men of their region immediately that everyone had been given two week's leave, after which they had to go by themselves or in small groups to Kroonstad and to leave their heavy ox-waggons behind, taking only with them, either riding horses or light two-wheeled carts driven by horses. After the retreat from Bloemfontein and its occupation by the English on March 13th, other commanders followed De Wet's example and the time came, when a further English advance to the North, could be met by the remnants of the Police Corps, which had survived the Abramskraal action, the reconnoitring detachment of Theron's volunteers and a few foreign detachments of very doubtful fighting quality, in all no more than 1000 men. The decision made by De Wet and after him by other commanders was the wisest one in the given circumstances. It was also wise to chose Kroonstad as a collecting point, for it could not become occupied by the enemy during the short period of leave. It was hoped that the enemy advance would be halted by the destruction of bridges and buildings on the railroad sector Bloemfontein-Kroonstad.

* Mrs Foxcroft, Russian by birth, was born in Poltava (the Ukraine). After the Revolution and the Civil War, during which her father an officer, lost his life, her mother and she escaped to Bulgaria and lived for some years there, then in France and England where Mrs Foxcroft was educated and received an Honours Degree and later an M.A. in Modern Languages, Russian and French at the University of Oxford. She married a South African at the beginning of the second World War and soon after its end came to live and settle in South Africa. On account of her qualifications she was appointed as the Head of the first department of Russian Studies in the first University to introduce Russian as a subject. Mrs Foxcroft remain in that position until her retirement in 1977. 